University of Nebraska - Lincoln

DigitalCommons@University of Nebraska - Lincoln

Diets of Lesser Scaup during Spring Migration throughout the Upper-Midwest are Consistent with the Spring Condition Hypothesis

\author{
Michael J. Anteau \\ Louisiana State University, Baton Rouge, manteau@usgs.gov \\ Alan Afton \\ U.S. Geological Survey
}

Follow this and additional works at: https://digitalcommons.unl.edu/usgsnpwrc

Part of the Other International and Area Studies Commons

Anteau, Michael J. and Afton, Alan, "Diets of Lesser Scaup during Spring Migration throughout the UpperMidwest are Consistent with the Spring Condition Hypothesis" (2008). USGS Northern Prairie Wildlife Research Center. 12.

https://digitalcommons.unl.edu/usgsnpwrc/12

This Article is brought to you for free and open access by the US Geological Survey at DigitalCommons@University of Nebraska - Lincoln. It has been accepted for inclusion in USGS Northern Prairie Wildlife Research Center by an authorized administrator of DigitalCommons@University of Nebraska - Lincoln. 


\title{
Diets of Lesser Scaup during Spring Migration throughout the Upper-Midwest are Consistent with the Spring Condition Hypothesis
}

\author{
Michael J. ANTEAU ${ }^{1,2}$ AND Alan D. AfTON ${ }^{3}$ \\ ${ }^{1}$ School of Renewable Natural Resources, Louisiana State University, Baton Rouge, LA 70803, USA \\ ${ }^{2}$ Present address: U.S. Geological Survey, Northern Prairie Wildlife Research Center, Jamestown, ND 58401, USA \\ Internet: manteau@usgs.gov
}

${ }^{3}$ U.S. Geological Survey, Louisiana Cooperative Fish and Wildlife Research Unit, Louisiana State University, Baton Rouge, LA 70803, USA

\begin{abstract}
The spring condition hypothesis (SCH) states that the current decline of the North American scaup population (Lesser [Aythya affinis] and Greater Scaup [A. marila] combined) is due to a decline in quality or availability of scaup foods on wintering, spring migration, or breeding areas that has caused a reduction in female body condition and subsequent reproductive success. Our previous research indicated that forage quality in diets of Lesser Scaup (hereafter scaup) at two sites in Northwestern Minnesota was lower in springs 2000-2001 than that reported for springs 1986-1988, consistent with the SCH. Accordingly, we further tested the SCH at a landscape scale, by comparing amounts of amphipods in diets (index of forage quality) of scaup ( $\mathrm{N}=263$ ) collected in springs 2003 2005 from seven eco-physiographic regions in Iowa, Minnesota, and North Dakota in relation to data from Northwestern Minnesota during springs 2000-2001. We found that aggregate percentages of Gammarus lacustris and Hyalella azteca (amphipods) in scaup diets during springs 2000-2001 in Northwest Minnesota were similar to those in the Iowa Prairie Pothole, Minnesota Morainal, Minnesota Glaciated Plains, Red River Valley, and Northwestern Minnesota in springs 2003-2005; however, scaup consumed relatively higher aggregate percentages of Gammarus lacustris and Hyalella azteca in North Dakota Missouri Coteau and North Dakota Glaciated Plains. Females in Iowa were over three times less likely to have consumed food than those in North Dakota, despite previous research indicating similar foraging rates among these regions. Mean mass of scaup diet samples throughout the upper-Midwest were $77 \mathrm{mg}(49 \%)$ and $87 \mathrm{mg}(52 \%)$ lower than those of historical studies in Minnesota and Manitoba, respectively. We conclude that there has been a decrease in forage quality for scaup in Iowa and Minnesota and a decrease in the amount of forage consumed throughout the upper-Midwest, consistent with the SCH. Received 20 September 2007, accepted 18 January 2008.
\end{abstract}

Key words. - amphipod, chironomid, fattening, food, lipid reserves, stopover area.

Waterbirds 31(1): 97-106, 2008

The continental scaup population (Lesser [Aythya affinis] and Greater Scaup [A. marila] combined) has declined markedly since 1978 (Austin et al. 1998; Afton and Anderson 2001); population estimates were lowest on record in 2006 (Wilkins et al. 2007). Afton and Anderson (2001) concluded that the decline in the continental scaup population likely is driven by declines in the Lesser Scaup population and caused by reductions in recruitment. The segment of the continental scaup population that winters in states bordering the Gulf of Mexico and migrates along the Mississippi River valley and through the upper-Midwest, comprises a major component of the continental population and this segment is experiencing the largest decline (Afton and Anderson 2001).

Nutrient reserves acquired during spring migration are important determinants of sur- vival and reproductive success in Lesser Scaup (hereafter scaup), and northern spring stopover areas are important for accumulation of these reserves (Afton 1984; Afton and Ankney 1991; Pace and Afton 1999; Anteau and Afton 2004). The Spring Condition Hypothesis (SCH) states that reproductive success of scaup has declined because females currently are in lower body condition during spring migration than in the past (Afton and Anderson 2001). Female scaup currently have fewer lipid reserves than did those historically (Anteau and Afton 2004; Anteau and Afton 2008a) and catabolize those lipid reserves as they migrate throughout the upper-Midwest in spring (Anteau 2006). Thus, results from these recent studies are consistent with the "lower body condition" prediction of the SCH.

Two other predictions of the SCH are that forage availability (abundance of prey) 
and/or quality (net nutritional benefit of prey) on northern stopover areas have declined. Historically, scaup consumed macroinvertebrates almost exclusively during spring, with amphipods being their predominant prey during spring and summer in the upper-Midwest (Rogers and Korschgen 1966; Bartonek and Hickey 1969; Swanson and Nelson 1970; Swanson and Duebbert 1989; Afton and Hier 1991; Afton et al. 1991). Use of particular wetlands by scaup in spring and summer is positively correlated with densities of amphipods (Lindeman and Clark 1999; Strand 2005; Anteau 2006). Scaup diets and foraging behavior indicate selection or evolved preference for amphipods during spring (Anteau 2006), thus fewer amphipods in scaup diets should indicate lower forage quality (Anteau and Afton 2006).

In Northwestern Minnesota, the percentage of amphipods in scaup diets was markedly (94\%) lower during springs 2000-2001 than that in historical diets (springs 19861988), and amphipod densities in wetlands across the upper-Midwest in 2004-2005 were low, suggesting that there has been a landscape-scale decline in amphipods (Anteau and Afton 2006; Anteau and Afton 2008b; Strand et al. 2008). The apparent decrease in amphipod densities in the upper-Midwest could lead to a decrease in amphipod consumption by scaup across this large landscape. Accordingly, we investigated scaup diets on northern spring stopover areas in the upper-Midwest because changes in forage quality or availability across a large landscape could have precipitous effects on female body condition and concomitant reproductive success (Anteau 2002; Austin et al. 2002; Anteau and Afton 2004, 2006, 2008a).

Specifically, we tested the prediction that forage quality has declined by comparing percentages of Gammarus lacustris (hereafter Gammarus) and Hyalella azteca (hereafter $\mathrm{Hy}$ alella) amphipods in diets (mean aggregate percent dry mass of taxa) of scaup collected during spring migration throughout the upper-Midwest in 2003-2005 to those of scaup in Northwest Minnesota in 2000-2001 (hereafter NW00). We used data from NW00 for reference because these data are the only data set available that are quantitatively referenced to historical diets of scaup during spring migration in the upper-Midwest. Thus, if scaup consumption of amphipods in the upper-Midwest is less than or equal to levels observed in NW00, this would indicate a regional decrease in forage quality in scaup diets.

We examined feeding success (proportion of females with food present), and food mass (mass of entire food sample), so that we could make inferences about the availability of foods on stopover areas in the upper-Midwest. Further, the amount of forage consumed is important to consider when calculating the amount of a given taxa that was consumed. We also explored regional differences in diet composition, so that we could make inferences about dietary selection of scaup migrating through the upper-Midwest in spring.

\section{METHODS}

Study Area

Our study area included the Prairie Pothole Regions of Iowa, Minnesota, and North Dakota (Fig. 1). This area comprises the most important spring migration stopover areas for scaup within the upper-Midwest, based on observations of wildlife biologists and managers, band-recovery data, sightings of color-marked scaup, and aerial surveys in spring (Low 1941; Afton and

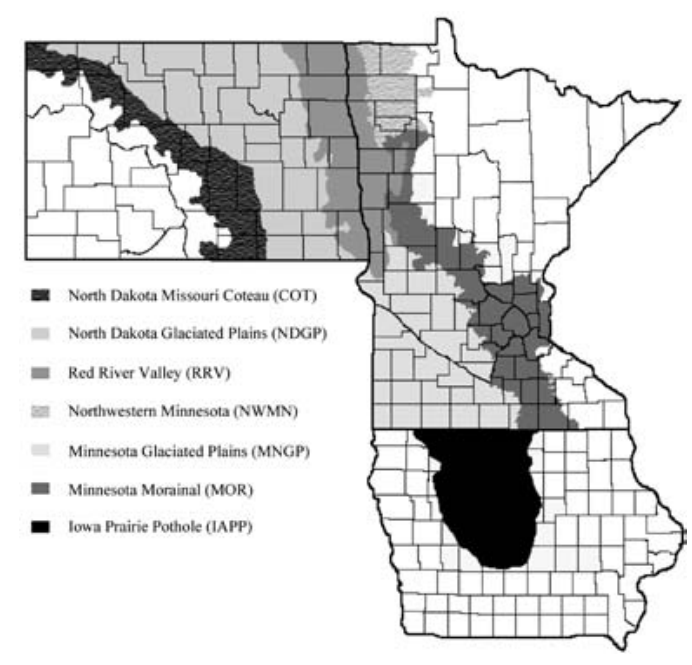

Figure 1. Map of the study area depicting 7 eco-physiographic regions for Lesser Scaup collections (20032005) during spring migration in the upper-Midwest. Areas in white were not sampled. 
Hier 1985; Afton et al. 1991; Pace and Afton 1999; Minnesota Department of Natural Resources, unpubl. data; North Dakota Game and Fish Department, unpubl. data). The three-state area was divided into seven ecophysiographic regions (hereafter regions) based on watershed and groundwater hydrology, geology, and plant communities (Fig. 1; Kantrud et al. 1989; Minnesota Department of Natural Resources, unpubl. data). The Minnesota Glaciated Plains (MNGP) and the Minnesota Morainal (MOR) regions included areas outside the traditional Prairie Pothole Region (Fig. 1); however, we included them so that results would be relevant to statespecific management and conservation plans.

\section{Sampling Design and Allocation}

Constrained-random sampling techniques were used to select collection sites in all regions except Northwestern Minnesota. Numbers of townships were first estimated within each region that had at least 200 hectares of semipermanent wetlands (candidate townships for random selection; Table 1), based on converged basin (Johnson and Higgins 1997) or comparable National Wetland Inventory data (c.f. Anteau 2006). In Iowa, the constraint was broadened to include townships with 200 ha of semipermanent or permanent wetlands. Numbers of collection sites were allocated among the six regions (three to six sites per region; Table 1) based on region size and number of candidate townships available (Table 1, Fig. 1). Each region was divided into approximately equal-sized sub-regions based on latitude, such that there was one collection site per sub-region each year (except in North Dakota Glaciated Plains [NDGP]). In NDGP, two collection sites were assigned for each sub-region because of the larger width of this region (east to west) relative to other regions (Fig. 1).

\section{Collection Sites}

Each collection site (27,972 ha) was comprised of three 36 -square-mile townships to ensure adequate collection opportunities; however, in some instances townships were replaced with another randomly selected township because the original selected township no longer had suitable scaup habitat (semipermanent or permanent wetlands) or had little or no scaup use (17\% of townships where collections occurred). Collections of ten females from each collection site was attempted. New townships were randomly selected annually within each sub-region from the list of candidate townships to maximize representation of spatial variability in scaup diets. In 2004 and 2005, township selection was further constrained so that centriods of the second and third townships selected were within $50 \mathrm{~km}$ of the first randomly selected township's centriod to minimize travel by field crews. In Northwestern Minnesota, collections were conducted on the same sites annually (Agassiz National Wildlife Refuge and Thief Lake and Roseau River Wildlife Management Areas; Table 1) thus, data were comparable to other data sets (Afton et al. 1991; Anteau and Afton 2006). Collections of 15 females from each of these fixed sites were attempted annually in 2003-2005 (hereafter NWMN).

\section{Collection of Specimens}

Collections, described below, were conducted exactly as in Afton et al. (1991) and Anteau and Afton (2004; 2006; 2008a), allowing for direct comparisons among these studies. Female scaup were collected randomly with a shotgun without the use of decoys to avoid associated biases (Pace and Afton 1999). In all regions, collections of foraging females were attempted so that feeding success and food mass would be comparable among regions. Collections were generally timed to occur during the middle of migration, coinciding with presence of relatively large numbers of migrating scaup. Diet samples were obtained from 263 scaup during springs 20032005 (Table 1); diet samples from 20 male scaup were included in our data set (collected in 2003-2005) because scaup diets in spring are similar between sexes (Afton et al. 1991; Afton and Hier 1991; Anteau and Afton 2006). In Iowa Prairie Pothole (IAPP) region, scaup and diet samples were only collected in 2004-2005.

\section{Specimen Preparation}

Immediately after collection, esophageal and proventricular contents were preserved by slowly injecting a $10 \%$ buffered formaldehyde solution down the

Table 1. Numbers of randomly selected collection sites each year (2003-2005), total numbers of Lesser Scaup diet samples (N), and candidate townships ( $T$ ) available for random selection of collection sites by eco-physiographic region.

\begin{tabular}{|c|c|c|c|}
\hline Region & Sites & $\mathrm{N}^{\mathrm{a}}$ & $\mathrm{T}$ \\
\hline North Dakota Missouri Coteau & 3 & 49 & $208^{\mathrm{b}}$ \\
\hline North Dakota Glaciated Plains & 6 & 73 & $364^{\mathrm{b}}$ \\
\hline Red River Valley & 3 & 25 & $66^{\mathrm{b}}$ \\
\hline Northwestern Minnesota & $3^{\mathrm{c}}$ & 37 & $\mathrm{n} / \mathrm{a}$ \\
\hline Minnesota Glaciated Plains & 4 & 41 & $285^{\mathrm{b}}$ \\
\hline Minnesota Morainal & 4 & 25 & $348^{\mathrm{b}}$ \\
\hline Iowa Prairie Pothole ${ }^{\mathrm{d}}$ & 3 & 13 & $43^{\mathrm{e}}$ \\
\hline Total & 26 & 263 & 1314 \\
\hline
\end{tabular}

${ }^{\text {a Includes }} 20$ males collected in 2003-2005.

${ }^{\mathrm{b}}$ Townships that contain at least 200 hectares of semipermanent wetlands.

'Fixed collection sites (see Methods).

${ }^{\mathrm{d}}$ Collections in 2004 and 2005 only.

'Townships that contain at least 200 hectares total of semipermanent and permanent wetlands. 
esophagus with a syringe. Specimens were labeled, placed in double plastic bags, frozen, and transported to the laboratory for dissection.

In the laboratory, specimens were thawed; all foods were removed from the upper-digestive tract (esophagus and proventriculus) and sorted exactly as described in Afton and Hier (1991), and Afton et al. (1991). Occasionally reflux or reverse movement of ingesta were detected from the gizzard into the upper-digestive tract (when food was absent in the upper-digestive tract). This resulted in the upper-gut containing seeds, shell fragments, and pebbles. This potential bias was minimized by excluding samples from the analysis that only had shell fragments, seeds, and pebbles in the uppergut, if ingesta matched that of the gizzard. Sorted foods were weighed $( \pm 0.0001 \mathrm{~g})$ after drying to a constant mass at $60^{\circ} \mathrm{C}$ (Anteau and Afton 2006). For subsequent analyses, foods were grouped taxonomically (response variables) as in Afton et al. (1991) and Anteau and Afton (2006); data were summarized by aggregate percent dry mass and percent occurrence (Swanson et al. 1974; Afton et al. 1991).

\section{Statistical Analyses}

Diet data were included from 22 scaup collected in 2000-2001 at Thief Lake and Roseau River (Anteau and Afton 2006) for reference; those data were included into subsequent analyses as a separate region (Northwestern Minnesota 2000-2001 [NW00]). Samples were pooled over years and it was assumed that annual variation was less important than spatial variability (Afton and Hier 1991; Afton et al. 1991; Anteau and Afton 2006; Anteau and Afton 2008b).

Aggregate percent dry mass of foods (Gammarus, $\mathrm{Hy}$ alella, bivalves, insects, gastropods, leeches, seeds; Table 2) were compared among regions with a multivariate analysis of variation (MANOVA; PROC GLM; SAS Institute 2002). A priori contrasts were conducted to test for differences in least-squares means of Gammarus and

Table 2. Aggregate percentage dry mass of taxa consumed by Lesser Scaup $(n=263)$ during spring migration in 2003-2005 by eco-physiographic regions (COT $=$ ND Missouri Coteau, NDGP $=$ ND Glaciated Plains, RRV $=$ Red River Valley of MN and ND, NWMN = Northwestern MN, MNGP = MN Glaciated Plains, MOR = MN Morainal, IAPP = IA Prairie Pothole). Totals of sub-taxa are indicated with bold typeface.

\begin{tabular}{|c|c|c|c|c|c|c|c|}
\hline Taxa & COT & NDGP & RRV & NWMN & MNGP & MOR & IAPP \\
\hline Amphipoda (scuds) & 55.4 & 48.6 & 19.5 & 20.4 & 7.9 & 23.4 & 2.7 \\
\hline Gammarus lacustris ${ }^{\mathrm{a}}$ & 37.4 & 26.3 & 15.8 & 17.5 & 4.3 & 16.0 & 0.0 \\
\hline Hyalella azteca ${ }^{\mathrm{a}}$ & 18.0 & 22.3 & 3.7 & 2.9 & 3.6 & 7.4 & 2.7 \\
\hline $\begin{array}{l}\text { Bivalves (Musculium sp.; fingernail } \\
\text { clams) }^{\mathrm{a}}\end{array}$ & 0.3 & $\mathrm{TR}^{\mathrm{b}}$ & 1.1 & 2.6 & 1.3 & 1.6 & 0.0 \\
\hline Anostraca (fairy shrimp) & 1.0 & 0.0 & 0.0 & 0.0 & 0.0 & 0.0 & 0.0 \\
\hline Ostracoda (mussel or seed shrimp) & 0.0 & 0.0 & 3.0 & 0.0 & 6.7 & 1.5 & 0.6 \\
\hline Insecta $^{a}$ & 31.3 & 33.9 & 54.2 & 49.0 & 45.8 & 49.3 & 63.6 \\
\hline Ceratopogonidae (biting midges) & 0.0 & 0.0 & $\mathrm{TR}$ & 0.0 & 0.3 & $\mathrm{TR}$ & 2.5 \\
\hline Chaoboridae (phantom midges) & 0.0 & 0.0 & 4.0 & 0.0 & 0.2 & 0.5 & 2.2 \\
\hline Chironomidae (true midges) & 26.4 & 25.3 & 43.2 & 46.8 & 42.7 & 34.4 & 50.8 \\
\hline Coleoptera (water beetles) & 0.1 & 1.2 & 0.0 & TR & 0.1 & 0.0 & 0.0 \\
\hline Corixidae (water boatmen) & 1.9 & 1.3 & TR & 0.1 & 1.3 & 4.3 & 0.0 \\
\hline Ephemeroptera (mayflies) & 0.0 & 0.0 & 0.0 & 0.0 & 0.3 & 9.5 & 0.0 \\
\hline Trichoptera (caddis flies) & 1.5 & 1.2 & 7.0 & 2.0 & 0.4 & 0.1 & 2.4 \\
\hline Zygoptera (damselflies) & 1.4 & 4.7 & $\mathrm{TR}$ & 0.1 & 0.5 & 0.3 & 0.0 \\
\hline Insect fragments & 0.0 & 0.2 & 0.0 & 0.0 & 0.0 & 0.2 & 5.7 \\
\hline Isopoda (freshwater hoglouse) & 0.0 & 0.0 & 0.0 & 0.0 & 0.0 & 0.1 & 0.0 \\
\hline Gastropoda $^{a}$ & 4.9 & 4.5 & 14.8 & 12.5 & 7.7 & 11.2 & 0.0 \\
\hline Hydrobiidae (spire snails) & 0.1 & 1.6 & 7.3 & 0.0 & 0.0 & 0.4 & 0.0 \\
\hline Physidae (pouch snails) & 1.5 & 0.4 & 2.9 & 0.1 & 0.8 & 0.7 & 0.0 \\
\hline Planorbidae (orb snails) & 3.3 & 2.5 & 4.6 & 9.2 & 4.5 & 10.1 & 0.0 \\
\hline Valvatidae (round-mouthed snails) & 0.0 & 0.0 & 0.0 & 2.7 & 2.4 & 0.0 & 0.0 \\
\hline Unidentified parts & 0.0 & 0.0 & 0.0 & 0.5 & 0.0 & 0.0 & 0.0 \\
\hline Oligochaeta (aquatic worms) & $\mathrm{TR}$ & 0.0 & 0.2 & 0.0 & 0.0 & 0.0 & 1.1 \\
\hline Hirudinea (leeches) ${ }^{\mathrm{a}}$ & 1.4 & 4.9 & 4.0 & 3.6 & 6.3 & 4.7 & 7.4 \\
\hline Hydrachnidae (water mites) & TR & TR & 0.0 & 0.0 & 0.1 & TR & 0.0 \\
\hline Fish and fish fragments & 0.0 & 1.2 & 0.1 & 0.0 & 0.0 & 0.0 & 7.6 \\
\hline Seeds (seeds, nutlets, achenes) ${ }^{\mathrm{a}}$ & 5.4 & 5.0 & 2.1 & 11.9 & 22.0 & 6.6 & 15.1 \\
\hline Vegetation fragments & TR & 0.3 & $\mathrm{TR}$ & 0.0 & 0.0 & 1.2 & 1.9 \\
\hline Tubers & 0.0 & 1.3 & 0.0 & 0.0 & 0.0 & 0.0 & 0.0 \\
\hline Algae (filamentous) & 0.0 & 0.0 & 0.0 & 0.0 & 2.4 & 0.0 & 0.0 \\
\hline
\end{tabular}

${ }^{\mathrm{a}}$ Response variable for MANOVA testing for regional effects.

${ }^{\mathrm{b}}$ Trace amounts $(<0.1 \%)$. 
Hyalella between each region and NW00 (Dunnett adjusted pdiff-control option; $\alpha=0.05$; PROC GLM; SAS Institute 2002). A posteri tests were then conducted to test for regional differences in bivalves, insects, gastropods, leeches, and seeds using Tukey-Kramer adjusted least-squares-mean groupings (pdiff-all option; alpha= 0.05; PROC GLM; SAS Institute 2002).

Regional variation in feeding success (number of females with diet samples over the total females collected in each region) was examined with a logistic regression (binomial distribution, logit link; PROC GENMOD; SAS Institute 2002). Diet sample mass (dry mass of total food sample) of scaup that had diet samples among regions were compared with an analysis of variance (ANOVA; PROC MIXED; SAS Institute 2002); diet sample mass were log-transformed to conform residuals to normality.

\section{RESULTS}

The overall composition of diets differed among regions $\left(\mathrm{F}_{7,277}=4.42 ; \mathrm{P}<0.001\right)$. Aggregate percentages of Gammarus and Hyalel$l a$ in NW00 were similar to those of IAPP, MOR, MNGP, Red River Valley (RRV), and NWMN; however, aggregate percentages of Gammarus and Hyalella in North Dakota Missouri Coteau (COT) and NDGP were higher than those in NW00 (Fig. 2). Aggregate percentage of leeches did not vary among regions $\left(\mathrm{F}_{7,277}=0.42, \mathrm{P}=0.891\right)$. Regional aggregate percentages of insects consumed generally were high (except NW00 in 20002001; Fig. 2), but were similar among regions after Tukey-Kramer adjustment for multiple comparisons (Fig. 2). Aggregate percentages of gastropods in NDGP, and COT were lower than those in NW00 and other regions (Fig. 2). Scaup consumed more bivalves in NW00 than in all other regions (Fig. 2). Aggregate percentages of seeds in scaup diets were higher in MNGP than that of those in RRV, NDGP, and COT. Scaup migrating through IAPP consumed primarily insects $(63.6 \%)$ and seeds (15.1\%; Fig. 2).

Percent occurrences of amphipods generally were higher and seeds were lower in COT, NDGP, and RRV than those in NWMN, MNGP, MOR, and IAPP (Table 3). Percent occurrences of bivalves generally were low in all regions, but highest in NWMN (Table 3 ).

Feeding success varied among regions $\left(\chi_{6,634}^{2}=17.97, \mathrm{P}=0.006\right.$; Fig. 3). Females in IAPP were $3.9\left(\chi_{1,634}^{2}=11.72, \mathrm{P}<0.001\right)$ and $3.0\left(\chi_{1,634}^{2}=8.44, \mathrm{P}=0.004\right)$ times less likely to have consumed food prior to collection than were those collected in COT and NDGP, respectively. Similarly, females in NWMN were $2.3\left(\chi_{1,634}^{2}=7.61, \mathrm{P}=0.006\right)$ and $1.7\left(\chi_{1,634}^{2}=4.25, \mathrm{P}=0.039\right)$ times less likely to have acquired food prior to collection than those in COT and NDGP, respectively. Among scaup that had consumed food, food masses were similar among regions $\left(\mathrm{F}_{6,256}=\right.$ $1.37 ; \mathrm{P}=0.227$; overall geometric mean $=79$ mg [dry]; 63-99 mg 95\% CL).

\section{DISCUSSION}

\section{Importance of Amphipods in Scaup Diets}

Several lines of evidence indicate that scaup prefer amphipods as food during spring migration in the upper-Midwest. First, amphipods historically were the predominate food item consumed by scaup in a variety of locations and years during spring and early summer (Rogers and Korschgen 1966; Bartonek and Hickey 1969; Swanson and Nelson 1970; Swanson and Duebbert 1989; Afton and Hier 1991; Afton et al. 1991). Second, scaup use of wetlands is positively correlated with amphipod densities (Lindeman and Clark 1999; Strand 2005; Anteau 2006), but not correlated with chironomid densities (Strand 2005; Anteau 2006), another frequently consumed food (this study; Anteau and Afton 2006). Third, scaup continue to consume amphipods at high aggregate percentages in NDGP and COT despite apparent declines in their availability across the upper-Midwest (Anteau and Afton 2008b). Fourth, percent occurrences of amphipods in scaup diets generally were high in all regions (this study) and in South Dakota (Strand et al. 2008).

Amphipods have higher gross energy, protein, and lipid content than do bivalves and gastropods (Jorde and Owen 1988; Ballard et al. 2004); amphipods also have higher true metabolizable energy than do bivalves and gastropods, when consumed by ducks (Sugden 1978; Jorde and Owen 1988; Ballard et al. 2004). Furthermore, lipid content of amphipods is highest in late fall and early spring (Mathias et al. 1982; Arts et al. 1995; 

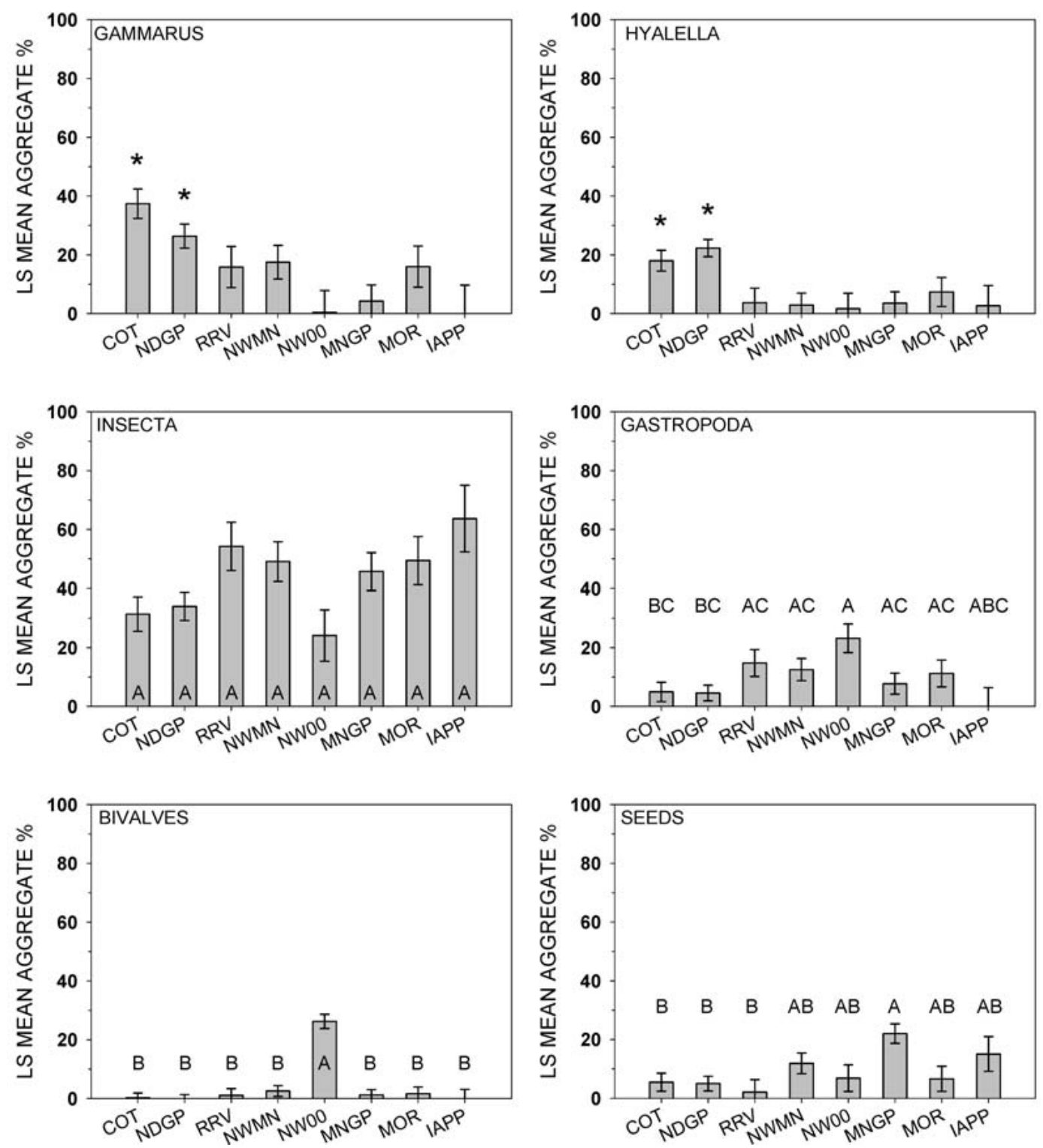

Figure 2. Least-square mean aggregate percent dry mass $( \pm \mathrm{SE})$ of foods consumed by Lesser Scaup collected during spring migration in 2003-2005 (unless otherwise stated) by region. Regions are depicted as: COT = ND Missouri Coteau, NDGP = ND Glaciated Plains, RRV = Red River Valley of MN and ND, NWMN = Northwestern MN, NW00 $=$ Northwestern MN (Thief Lake and Roseau River WMAs) in 2000-2001 (see Anteau and Afton 2006), MNGP = MN Glaciated Plains, MOR = MN Morainal, and IAPP = IA Prairie Pothole. Asterisks indicate significance $(P<0.05)$ of Dunnett adjusted $a$ priori contrasts between each region and NW00 within Gammarus and Hyalella plots. Capital letters are Tukey-Kramer adjusted mean grouping for a posteri contrasts of each taxa between regions; means with the same letter are similar $(P<0.05)$.

Meier et al. 2000), whereas lipid content of bivalves and insects generally peak in mid to late summer (Davis and Wilson 1983; Meier et al. 2000). Finally, scaup are more efficient at assimilating energy from amphipods than other ducks (see Sugden 1978; Jorde and
Owen 1988; Ballard et al. 2004), suggesting that scaup are highly adapted for foraging on amphipods. Accordingly, the apparent decreases in the percentage of amphipods in scaup diets during spring migration in Iowa and Minnesota reflects a decrease in forage 
Table 3. Percent occurrence of major taxa consumed by Lesser Scaup $(n=263)$ during spring migration in 20032005 by eco-physiographic regions (COT $=$ ND Missouri Coteau, NDGP $=$ ND Glaciated Plains, RRV $=$ Red River Valley of MN and ND, NWMN = Northwestern MN, MNGP = MN Glaciated Plains, MOR = MN Morainal, IAPP = IA Prairie Pothole).

\begin{tabular}{lcccrrrr}
\hline \hline Taxa & COT & NDGP & RRV & NWMN & MNGP & MOR & IAPP \\
\hline Amphipoda (scuds) & 76 & 68 & 60 & 37 & 29 & 44 & 15 \\
Gammarus lacustris & 53 & 40 & 28 & 22 & 7 & 16 & 0 \\
Hyalella azteca & 37 & 47 & 52 & 22 & 27 & 28 & 15 \\
Bivalves (Musculium sp.; fingernail clams) & 2 & 1 & 12 & 31 & 2 & 8 & 0 \\
Insecta & 63 & 66 & 80 & 85 & 73 & 68 & 92 \\
Gastropoda & 24 & 18 & 36 & 46 & 29 & 28 & 0 \\
Hirudinea (leeches) & 14 & 22 & 16 & 25 & 17 & 16 & 8 \\
Seeds (seeds, nutlets, achenes) & 27 & 29 & 28 & 56 & 54 & 48 & 46 \\
\hline
\end{tabular}

quality for scaup stopping over in those areas (Anteau and Afton 2006).

In the $1960 \mathrm{~s}$, aggregate percentages of amphipods in scaup diets, during spring and early summer throughout the Prairie Pothole Region, ranged from 46-67 (Rogers and Korschgen 1966; Bartonek and Hickey 1969; Swanson and Nelson 1970; Swanson and Duebbert 1989). In the 1980s, aggregate percentages of amphipods ranged from 29-33 (Afton and Hier 1991; Afton et al. 1991) and aggregate percentages were $94 \%$ lower in Northwestern Minnesota in 2000-2001 (Anteau and Afton 2006). Thus, historical data and our results are consistent with a decline in aggregate percentages of Gammarus and Hyalella amphipods consumed by scaup in Iowa and Minnesota. Unfortunately, historical quantitative data for amphipod consumption are not available for regions other than NWMN, thus precluding more rigorous tests. However, the current low percentages of amphipods consumed throughout Iowa and Minnesota coupled with evidence that amphipod densities have decreased in the upper-Midwest (Anteau and Afton 2008b) strongly suggests that there has been a landscape scale decrease in the availability of amphipods, which is consistent with the $\mathrm{SCH}$.

Aggregate percentages of amphipods in scaup diets in NDGP and COT were similar to that of historical scaup diets. However, examining percentages of amphipods consumed does not provide information about the amount of amphipods consumed unless the amount of forage consumed is similar among groups of interest. Geometric means of diet sample mass observed in this study were $77 \mathrm{mg}$ $(49 \%)$ and $87 \mathrm{mg}(52 \%)$ lower than those of historical studies in Minnesota and Manitoba, respectively (Afton and Hier 1991; Afton et al. 1991), despite similar collection procedures used among studies (see Anteau and Afton 2006). Thus, scaup apparently are consuming lower mass of amphipods throughout the upper-Midwest than they did historically.

Implications of Forage Resources on Scaup Energetics

Female scaup migrating throughout the upper-Midwest during springs 2003-2005 (including NDGP and COT) had low lipidreserve levels (Anteau and Afton 2008a) and

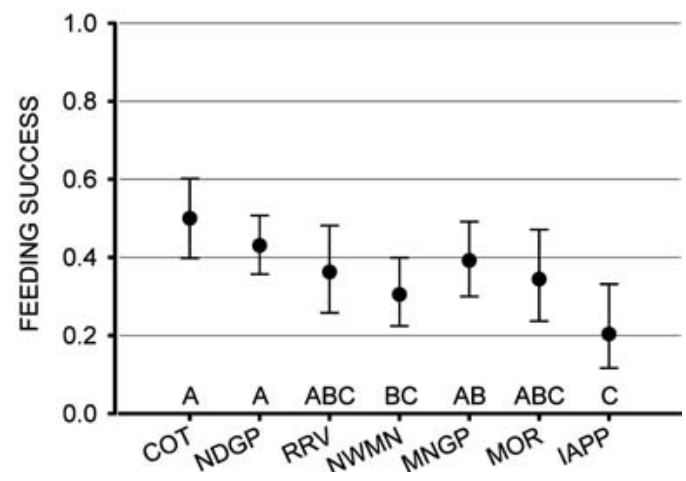

Figure 3. Least-squares mean probability of scaup collected that had consumed food (feeding success; $\pm 95 \%$ CI) by regions in the upper-Midwest in springs 20032005. The regions are depicted as: COT $=$ ND Missouri Coteau, NDGP = ND Glaciated Plains, RRV = Red River Valley of MN and ND, MNGP = MN Glaciated Plains, MOR = MN Morainal, and IAPP = IA Prairie Pothole. Means with same capital letter are similar $(P>0.05)$. 
were catabolizing lipid reserves (Anteau 2006); thus, scaup apparently were not meeting their dietary requirements in these regions. Foraging efficiency of scaup (intraand inter-wetland) probably has decreased because amphipod densities currently are lower than that of historical levels (Anteau and Afton 2008b), and anthropogenic influences on wetlands (i.e., sedimentation and fish introductions) may be interfering with cues (e.g., turbidity of wetlands) that scaup use to identify wetlands with abundant amphipods (Anteau 2006; Anteau and Afton 2008b). Consequently, females currently might be expending more energy to procure a diet of amphipods.

Female scaup migrating through IAPP in 2004 and 2005 were catabolizing lipid reserves at higher rates than for any other region (Anteau 2006). Females collected in IAPP were over 3 times less likely to have consumed food than those collected in NDGP or COT; however, the probability that scaup were observed foraging on wetlands in IAPP was similar to those in NDGP and COT (Anteau 2006). Based on these previously published findings and our diet analyses, we conclude that energetic costs of foraging exceeded dietary energy gained in IAPP. Concomitantly, the lower likelihood of females having consumed food in IAPP resulted in small sample size of scaup diets there, which made precision of tests between IAPP and other regions low.

\section{Landscape-Scale Inferences of Dietary Preferences of Scaup}

Diets of ducks are influenced by relative availability of foods and preferences for particular food items. Preference is driven by a number of factors including: energetic or nutritional requirements, foraging adaptations (e.g., bill morphology, diving vs. dabbling), and competition among species (i.e., niche formation; Afton and Hier 1991; Alisauskas and Ankney 1992; Krapu and Reinecke 1992). Spatial variation in availability of macroinvertebrate foods is large among wetlands in spring (Anteau and Afton 2008b; M. J. Anteau, unpubl. data). Thus, collecting diet samples over a large landscape should allow inferences about diet preference, based on mean percentages of foods consumed because relative availability is essentially averaged-over at a large landscapescale. However, if there are landscape-wide decreases in the availability of a particular food item this may not hold true.

Our results suggest that scaup select insects when amphipods are not available because insect consumption by scaup generally was high across this large landscape. Our results are consistent with the prediction that bivalve and gastropod consumption by scaup in the upperMidwest is a result of lack of availability of other preferred foods (Anteau and Afton 2006) because bivalve and gastropod consumption were generally low, except NWMN in 20002001 where amphipod consumption was low. In contrast, scaup primarily consume bivalves and gastropods during spring on the Lower Great Lakes and at Pool 19 of the Mississippi River (Badzinski and Petrie 2006; M.J. Anteau, unpubl. data); thus, when at very high densities, as reported for these particular areas, bivalves and gastropods apparently can be relatively profitable foods (Anteau 2002, 2006; Badzinski and Petrie 2006).

Regional percent occurrences of seeds appear inversely correlated with those of amphipods. Recent studies have reported very high seed consumption by scaup in the absence of abundant amphipod forage (Smith 2007; Strand et al. 2008). Seeds may be consumed by scaup, in the absence of amphipods, to accumulate lipid reserves because seeds can be a good source of carbohydrates and lipids (Afton and Hier 1991; Ballard et al. 2004).

\section{Conclusions}

We found that forage quality of scaup apparently has declined in Iowa and Minnesota and overall mass of foods consumed throughout the upper-Midwest was low in relation to historical data. Moreover, our results are consistent with the prediction of the $\mathrm{SCH}$ that the observed recent decrease in body condition of female scaup in the upperMidwest was caused by a decline in availability and/or quality forage (Anteau 2002, 2006; Anteau and Afton 2004, 2006, 2008a; 
Anteau et al. 2007). Based on our results and others, management activities that increase the availability of amphipods to female scaup at spring stopover areas in the upper-Midwest could help increase body condition of female scaup and perhaps indirectly increase recruitment rates, and, thus aid in reversing the long-term population decline.

\section{ACKNOWLEDGMENTS}

We thank the following for assistance with collection of birds or laboratory analyses: L. Ball, R. Brady, W. Brininger Jr., P. Bultsma, S. Caron, R. Durham, R. Faulkner, A. Greer, A. Hancock, D. Hoffman, J. Huener, R. Jensen, J. Kavanagh, A. Leach, J. Leslie, P. Mathews, S. McLoed, R. Meidinger, B. Meixell, D. Nelson, M. Olinde, R. Olsen, R. Renner, D. Soehren, S. Solieu, S. Stephens, M. Szymanski, A. Tobiason, T. Vidrine, J. Vorland, J. Walker, R. Warhurst, and G. Zenner. We acknowledge numerous landowners that allowed us to work on their property. We thank M. Anderson, A. Anteau, J. Austin, B. Batt, J. Berdeen, F. Bolduc, E. Bowers, T. Bishop, K. Brennan, R. Durham, J. Fernandez, M. Gulick, A. Hancock, R. Helm, D. Hertel, R. Hier, K. Howard, M. Johnson, R. Johnson, J. Lawrence, C. Loesch, J. Markl, R. Markl, T. Michot, E. Moser, W. Norling, J. Nyman, M. Ohide, B. Pardo, S. Piepgras, D. Rave, R. Reynolds, J. Ringelman, F. Rohwer, T. Rondeau, B. Schultz, S. Stephens, M. Szymanski, P. Telander, B. Wehrle, and G. Zenner for their help or support of the project. We thank the following organizations for financial or in-kind support: Ducks Unlimited, Inc., USA, Federal and Winchester Cartridge Companies, Iowa Department of Natural Resources, IWWR of Ducks Unlimited Canada, IWWR of Ducks Unlimited Canada-through the Bonnycastle Fellowship, Louisiana Department of Wildlife and Fisheries, Louisiana State University-through the Bosch Fellowship, Minnesota Department of Natural Resources, Minnesota Waterfowl Association, North Dakota Game and Fish Department, Prairie Pothole Joint Venture, Upper Mississippi River and Great Lakes Region Joint Venture, USFWS Regions 3 and 6 HAPET offices, USGS-Louisiana Cooperative Fish and Wildlife Research Unit, and USGS-National Wetland Research Center. Lastly, we thank S. Badzinski, M. Szymanski, D. Haukos, and K. Hobson for helpful comments on the manuscript.

\section{LITERATURE CiTED}

Afton, A. D. 1984. Influence of age and time on reproductive performance of female Lesser Scaup. Auk 101: 255-265.

Afton, A. D., and M. G. Anderson. 2001. Declining scaup populations: a retrospective analysis of longterm population and harvest survey data. Journal of Wildlife Management 65: 781-796.

Afton, A. D., and C. D. Ankney. 1991. Nutrient-reserve dynamics of breeding Lesser Scaup: a test of competing hypotheses. Condor 93: 89-97.

Afton, A. D., and R. H. Hier. 1985. Fall migration ecology of Lesser Scaup in Minnesota. Minnesota Depart- ment of Natural Resources Wildlife Research Unit Report: 74-94.

Afton, A. D., and R. H. Hier. 1991. Diets of Lesser Scaup breeding in Manitoba. Journal of Field Ornithology 62: 325-334.

Afton, A. D., R. H. Hier, and S. L. Paulus. 1991. Scaup diets during migration and winter in the Mississippi Flyway. Canadian Journal of Zoology 69: 328-333.

Alisauskas, R. T., and C. D. Ankney. 1992. The cost of egg laying and its relationship to nutrient reserves in waterfowl. Pages 30-61 in Ecology and management of breeding waterfowl (B. D. J. Batt, A. D. Afton, M. G. Anderson, C. D. Ankney, D. H. Johnson, J. A. Kadlec, and G. L. Krapu, Eds.). University of Minnesota Press, Minneapolis.

Anteau, M. J. 2002. Nutrient reserves of lesser scaup during spring migration in the Mississippi Flyway: a test of the Spring Condition Hypothesis. MS thesis, Louisiana State University, Baton Rouge, Louisiana. http://etd.lsu.edu/docs/available/etd-0707102155816, accessed 20 September 2007.

Anteau, M. J. 2006. Ecology of lesser scaup and amphipods in the upper-Midwest: scope and mechanisms of the Spring Condition Hypothesis and implications for migration habitat conservation. Ph.D. dissertation, Louisiana State University, Baton Rouge, Louisiana, USA. http://etd.lsu.edu/docs/available/etd01242006-093828, accessed 20 September 2007.

Anteau, M. J., and A. D. Afton. 2004. Nutrient reserves of Lesser Scaup during spring migration in the Mississippi Flyway: a test of the Spring Condition Hypothesis. Auk 121: 917-929.

Anteau, M. J., and A. D. Afton. 2006. Diet shifts of lesser scaup are consistent with the spring condition hypothesis. Canadian Journal of Zoology 84: 779-786.

Anteau, M. J., and A. D. Afton. 2008a. Landscape-wide low lipid reserves of Lesser Scaup during migration are consistent with the Spring Condition Hypothesis. In review.

Anteau, M. J., and A. D. Afton. 2008b. Amphipod densities and indices of wetland quality across the upperMidwest, USA. Wetlands 28: 184-196.

Anteau, M. J., A. D. Afton, C. M. Custer, and T. W. Custer. 2007. Influences of cadmium, mercury, and selenium on nutrient reserves of female lesser scaup during winter and spring migration. Environmental Toxicology and Chemistry 26: 515-520.

Arts, M. T., M. E. Ferguson, N. E. Glozier, R. D. Robarts, and D. B. Donald. 1995. Spatial and temporal variability in lipid dynamics of common amphipods: assessing the potential for uptake of lipophilic contaminants. Ecotoxicology 4: 91-113.

Austin, J. E., A. D. Afton, M. G. Anderson, R. G. Clark, C. M. Custer, J. S. Lawrence, J. B. Pollard, and J. K. Ringelman. 2000. Declining scaup populations: issues, hypotheses, and research needs. Wildlife Society Bulletin 28: 254-263.

Austin, J. E., C. M. Custer, and A. D. Afton. 1998. Lesser scaup (Aythya affinis). The birds of North America, Number 338. The American Ornithologists' Union, Washington, D.C., USA, and the Academy of Natural Sciences, Philadelphia, PA.

Austin, J. E., D. G. Granfors, M. A. Anderson, and S. C. Kohn. 2002. Scaup migration patterns in North Dakota relative to temperatures and water conditions. Journal of Wildlife Management 66: 874-882.

Badzinski, S. S., and S. A. Petrie. 2006. Diets of Lesser and Greater Scaup during autumn and spring on 
the Lower Great Lakes. Wildlife Society Bulletin 34: 664-674.

Ballard, B. M., J. E. Thompson, M. J. Petrie, M. Chekett, and D. G. Hewitt. 2004. Diet and nutrition of northern pintails wintering along the southern coast of Texas. Journal of Wildlife Management 68: 371-382.

Bartonek, J. C., and J. J. Hickey. 1969. Food habits of canvasbacks, redheads, and Lesser Scaup in Manitoba. Condor 71: 280-290.

Davis, J. P., and J. G. Wilson. 1983. Seasonal changes in tissue weight and biochemical composition of the bivalve Nucula turgida in Dublin Bay with reference to gametogenesis. Netherlands Journal of Sea Research 17: 84-95.

Johnson, R. R., and K. F. Higgins. 1997. Wetland resources of eastern South Dakota. South Dakota State University, Brookings, South Dakota. http://www. npwrc.usgs.gov/resource/wetlands/sdwet/sdwet.htm

Jorde, D. G., and R. B. Owen. 1988. Efficiency of nutrient use by American black ducks wintering in Maine. Journal of Wildlife Management 52: 209-214.

Kantrud, H. A., G. L. Krapu, and G. A. Swanson. 1989. Prairie basin wetlands of North Dakota: a community profile. Biological report $85(7.28)$, U.S. Department of the Interior, Fish and Wildlife Service, Research and Development, Washington, D.C.

Krapu, G. L., and K. J. Reinecke. 1992. Foraging ecology and nutrition. Pages 1-29 in B. D. J. Batt, A. D. Afton, M. G. Anderson, C. D. Ankney, D. H. Johnson, J. A. Kadlec, and G. L. Krapu [eds.], Ecology and management of breeding waterfowl. University of Minnesota Press, Minneapolis.

Lindeman, D. H., and R. G. Clark. 1999. Amphipods, land-use impacts, and Lesser Scaup (Aythya affinis) distribution in Saskatchewan wetlands. Wetlands 19: 627-638.

Low, J. B. 1941. Spring flight of diving ducks through northwestern Iowa. Condor 43: 142-151.

Mathias, J. A., J. Martin, M. Yurkowski, J. G. I. Lark, M. Papst, and J. L. Tabachek. 1982. Harvest and nutritional quality of Gammarus lacustris for trout culture. Transactions of the American Fisheries Society 111: 83-89.

Meier, G. M., E. I. Meyer, and S. Meyns. 2000. Lipid content of stream macroinvertebrates. Archive of $\mathrm{Hy}-$ drobiology 147: 447-463.
Pace, R. M. III, and A. D. Afton. 1999. Direct recovery rates of Lesser Scaup banded in northwest Minnesota: sources of heterogeneity. Journal of Wildlife Management 63: 389-395.

Rogers, J. P., and L. J. Korschgen. 1966. Foods of Lesser Scaups on breeding, migration, and wintering areas. Journal of Wildlife Management 30: 258-264.

SAS Institute. 2002. SAS/STAT user's guide, version 9. SAS Institute, Cary, NC.

Smith, R. V. 2007. Evaluation of waterfowl habitat and spring food selection by Mallard and Lesser Scaup on the Swan Lake, Illinois Habitat Rehabilitation and Enhancement Project. Thesis, Southern Illinois University, Carbondale.

Strand, K. A. 2005. Diet and body composition of migrating Lesser Scaup (Aythya affinis) in Eastern South Dakota. Thesis, South Dakota State University, Brookings.

Strand, K. A., S. R. Chipps, S. N. Kahara, K. F. Higgins, and S. Vaa. 2008. Pattern of prey use by Lesser Scaup Aythya affinis (Aves) and diet overlap with fishes during spring migration. Hydrobiologia: In press.

Sugden, L. G. 1978. Metabolizable energy of wild duck foods. Program Notes, Canadian Wildlife Service, Western Region, Saskatoon, Saskatchewan, Number 35.

Swanson, G. A., and H. F. Duebbert. 1989. Wetland habitats of waterfowl in the prairie pothole region. Pages 228-267 in Northern Prairie Wetlands (A. G. van der Valk, Ed.). Iowa State University Press, Ames.

Swanson, G. A., G. L. Krapu, J. C. Bartonek, J. R. Serie, and D. H. Johnson. 1974. Advantages in mathematically weighting waterfowl food habits data. Journal of Wildlife Management 38: 302-307.

Swanson, G. A., and H. Nelson. 1970. Potential influence of fish rearing programs on waterfowl breeding habitat. Pages 65-71 in Symposium on the Management of Midwestern Winterkill Lakes (E. Schneberger, Ed.). North Central Division of the American Fisheries Society, Winnipeg, Manitoba.

Wilkins, K. A., M. C. Otto, G. S. Zimmerman, E. D. Silverman, and M. D. Koneff. 2007. Trends in duck breeding populations, 1955-2007. U.S. Department of the Interior, Fish and Wildlife Service, Administrative Report, Laurel, MD. 